\title{
The Digital Divide in Inclusive Classrooms
}

\author{
Badriya AlSadrani, Mohammed Alzyoudi, \\ Negmeldin Alsheikh and Elazab Elazab Elshazly \\ College of Education \\ United Arab Emirates University \\ Al-Ain, United Arab Emirates
}

\begin{abstract}
The digital divide affects equity in inclusive classrooms. It can create a gap in accessing information-communication-technology (ICT) resources or inequalities in skills and effective use. The present study is a qualitative SWOT analysis; it explores teachers' views on access and use issues that widen the digital divide in inclusive classrooms in the UAE. Six teachers from intermediate and secondary-level schools were interviewed to identify the strengths, weaknesses, opportunities, and threats associated with ICT use and access in their inclusive classrooms. The semi-structured interviews were analyzed, using thematic analysis. The study found that, although all of the students, irrespective of disabilities, have equal access to ICT resources, various factorsincluding a lack of training, insufficient resources, heavy workloads, and a shortage of human resources-are expanding the digital divide in inclusive classrooms. This study discusses ways to overcome the challenges and implications; it recommends research avenues for future studies.
\end{abstract}

Keywords: Digital divide; inclusive classroom; disabilities; ICT; SWOT

\section{Introduction}

Information and communication technology (ICT) has become ubiquitous; it is part of people's daily activities (OECD, 2000; Wu, Chen, Yeh, Wang, \& Chang, 2014). Recent statistics estimate that 4.1 billion people around the world-more than half the total global population - used the Internet in 2017 (Warf, 2018). ICT promotes social interaction and plays a significant role in the education process, as well as equalizing learning practice (Assimwe \& Khan, 2013; Elen et al., 2010). Several studies have proven the benefits of ICT for students without disabilities (Assimwe \& Khan, 2013; Basak \& Govender, 2015; Dobransky \& Hargittai, 2016; Knott, Steube, \& Yang, 2013). Likewise, ICT has been shown to be beneficial for students with disabilities, as it enhances learning and facilitates their participation in classroom activities (Batorowicz, Missiuna, \& Pollock, 2012; Obradović, Bjekić, \& Zlatić, 2015; Wu et al., 2014). 
While nations are striving to promote equity in education through inclusive education (Anati, 2012; Leatherman \& Niemeyer, 2005; Moriña, 2017), the influence of ICT on equal classroom practice has become an issue (Mølster, 2016; $\mathrm{Wu}$ et al., 2014). Inequality in the extent to which disadvantaged students are able to access and use ICT has created a digital divide (Van Dijk, 2012). A digital divide has been described as the gap between those who have access to ICT services (such as the Internet) and related content and those who do not (Sossa, Rivilla, \& González, 2015). However, Van Dijk (2012) has extended the definition to include the motivation, skills, and usage of ICT. To enhance equal learning opportunities in inclusive education, all students must have equal access to and the ability to use ICT resources. To date, few studies have explored digital access, usage, and skills for students with disabilities in inclusive classrooms. The present study therefore focuses on exploring the challenges and opportunities associated with the equal use of ICT in inclusive classrooms.

Knowledge of different forms of technology, including the use of ICT, is essential in the twenty-first century; it also creates an area of focus, in which the ability to access and use such services is limited to certain individuals in society (OECD, 2000). Technology have been shown to be beneficial for all students, with or without disabilities (Batorowicz et al., 2012; Dobransky \& Hargittai, 2016; Wu et al., 2014). However, it is impractical to use ICT and other technological processes in inclusive classrooms if this practice creates other forms of social segregation for students with special needs. Access inequality and the challenges that some students experience when using ICT creates a digital divide. This issue mainly arises when limited resources and limited competencies make it difficult for students with special needs to access and benefit from ICT and other technological resources, in comparison to peers without special needs. Although many countries have discussed the digital divide affecting special-needs students (Dobransky \& Hargittai, 2016; Arais, 2019; Mølster, 2016; Wu et al., 2014), there is little research on this issue within the context of the UAE. This study will add to the literature from a different contextual perspective, while reinforcing the digitaldivide issue within the literature. It will also identify potential policy recommendations and instructions in this area. This study will try to answer this question: What views do public school teachers hold on the strengths, weaknesses, opportunities, and threats associated with equal ICT access and use in inclusive classrooms?

The present study explores issues related to the digital divide between specialneeds students and their non-disabled peers, based on the perspectives of cycletwo and -three teachers' within the UAE context. It examines the challenges and opportunities for equal ICT use in inclusive classrooms. The study provides a comprehensive overview of the ways in which equality is handled in UAE inclusive classrooms. To foster inclusivity and equity and highlight the need to incorporate technological processes effectively in classroom activities, this study will focus on ICT access and skills in inclusive classrooms. Thereafter, the present study will answer this following question: What are the public-school teachers' views about the strengths, weaknesses, opportunities, and threats for the equal ICT access and use in inclusive classroom? 
2. Conceptual Framework

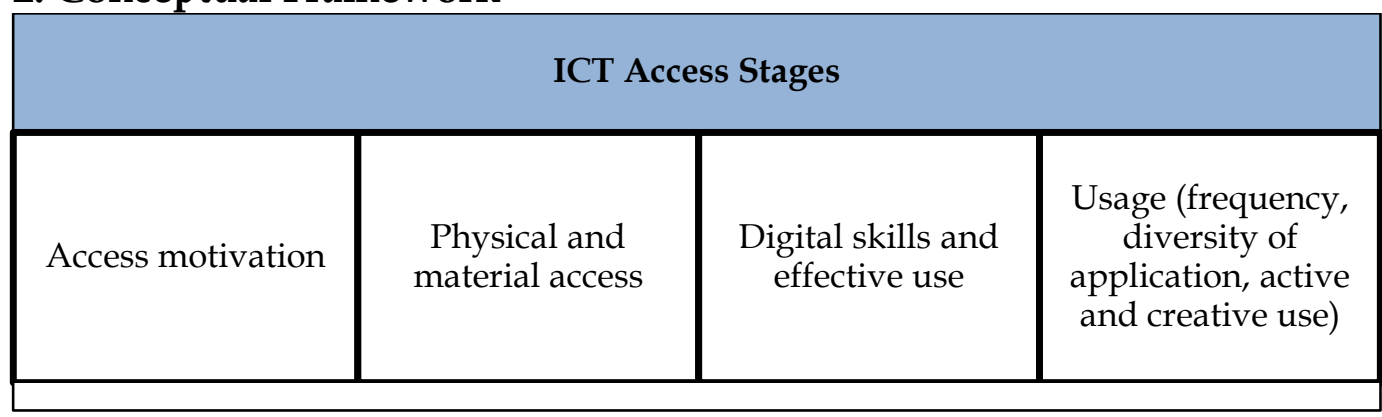

Figure 1. The Van Dijk Stages of ICT Access

The conceptual framework of this study is based on Van Dijk (2012), who argued that the digital access gap could be divided into differentiated stages (see Figure 1). These stages were as follows: access motivation, physical and material access, digital competencies and effective use, and usage. The interaction between motivation, materials, skills, and usage explains the digital divide (Jupin, 2019; Ghobadi, \& Ghobadi, 2013). The motivation gap is a lack of desire to access ICT tools (Van Dijk, 2012; Yuen, Park, \& Cheng, 2016); the desire to access is considered a prerequisite for using ICT (Van Dijk, 2012). For this reason, students with and without disabilities should be equally encouraged to access ICT; this must be done by providing materials, resources, and skills to adapt technology in inclusive classrooms.

The physical access gap can be prevented through the equal distribution of ICT resources to all schools. To avert a digital-skills gap and promote equal technology usage in inclusive classrooms, students must acquire core skills and learn to use ICT tools effectively to enhance their own learning. These skills go beyond the capacity to use hardware and software; they involve to searching for information, communicating, and creating content (Van Dijk, 2013). The usage gap reflects the frequency, variety of usage applications, and active, creative use of technology involved in ICT usage in daily life (Van Dijk, 2013). For example, when some students have more frequent access to the Internet than others, the usage gap increases. This suggests that teachers should not limit the ICT-related creativity of special-needs students, but should instead raise their expectations, just as they would for students without disabilities (Obradović et al., 2015).

The digital divide is the gap in ICT-resource distribution, technical knowledge, and usage effectiveness (Van Dijk, 2012). It is a challenge facing all nations, in relation to access, ICT skills, and appropriate use (Yuen et al., 2016). While access to ICT remains important, individuals with access to technology can have unequal skills or usage (Van Dijk, 2013). The success and sustainability of technologies used in educational settings are also determined by the accessibility and quality of ICT support (Damodaran \& Sandhu, 2016). Various studies have shown that narrowing the digital divide in inclusive classrooms can foster learning equality and improve the quality of life for marginalized students with special needs (Batorowicz et al., 2012; Chadwick, Caroline \& Fullwood, 2013; Clarida, Bobeva, Hutchings, \& Taylor, 2015; Mølster, 2016; Wu et al., 2014). To facilitate equity in ICT access and usage, we need to understand the challenges behind the digital 
divide. We also need to explore opportunities to incorporate technology effectively in inclusive classrooms, using the Van Dijk (2012) access-gap model (motivation, physical and material access, skills, and ICT usage).

\subsection{Access Motivation}

A lack of interest in learning new technologies widens the digital gap between students (Ghobadi, \& Ghobadi, 2013). The lack of motivation to access technologies is associated with a reduced desire to access or use ICT resources, such as Internet connections, social-interaction platforms, and search engines; this is related to various socio-economic factors, including a lack of education and low economic status (Ghobadi, \& Ghobadi, 2013). For example, students with less desire to access or use ICT are likely to be inactive in their use of technology, relative to their active classmates. Some individuals are satisfied with a basic computer or smartboard and have little interest in learning advanced ICT skills (Yuen et al., 2016). If these individuals are teachers, their attitude may reduce students' motivation to access ICT, thus creating digital inequity.

Lack of time is another factor that influences a teacher's desire to access and use ICT (Basak \& Govender, 2015; Ghobadi, \& Ghobadi, 2013; Raman \& Yamat, 2014; Van Dijk, 2013). A study carried out by Raman and Yamat (2014) revealed that, in schools with substantial resources, the teachers' workloads, lack of time, lack of ICT skills, and teaching experiences affected their motivation to use ICT in the classroom. Time pressure can negatively affect the integration of ICT into teaching content if teachers are struggling with a demanding curriculum or workload (Basak \& Govender, 2015; Raman \& Yamat, 2014). However, the relationship between ICT and workload is a controversial issue because some teachers believe that ICT reduces the workload and increases classroom productivity (Basak \& Govender, 2015; Sahito \& Vaisanen, 2017). Various factors can hinder a teacher's ability to integrate ICT into an inclusive classroom, shaping student attitudes toward technology and preventing students with and without disabilities from accessing and using ICT.

Lidström and Hemmingsson (2014) carried out an extensive literature review on the extent to which students with visual, speech, and motor impairments benefit from using digital technologies in school activities. The researchers compiled 32 studies, half of which were intervention studies. Most of the studies involved learners with motor impairments. In their results, the authors indicated that the types of ICT used to teach students with disabilities varied in accordance with the type of disability. Moreover, digital assistive technologies offered clear benefits for students learning to write, spell, and communicate (Lidström \& Hemmingsson, 2014). These advantages should be strengthened by integrating ICT into inclusive classrooms to enhance the learning of students with special needs.

Martínez (2011) investigated whether students with disabilities had the necessary resources and support from teachers to use adapted forms of ICT appropriately in inclusive classrooms. The study recruited a sample of 37 students with special needs, enrolled at a university and secondary school in Spain. The use of ICT, student experiences, and the support provided by teachers to students with 
disabilities were analyzed using a questionnaire. The study results indicated that students with disabilities felt ready to use ICT resources in their classrooms (Martínez, 2011), but that teachers did not offer students with disabilities the support they needed. The special-needs students felt that their teachers did not try to adapt the ICT resources or modify the available technology to accommodate their disabilities (Martínez, 2011).

\subsection{Physical and Material Access}

Although some researchers have argued that physical access to computers, the Internet, and mobile technology closes the digital divide (Van Dijk, 2017), there is a gap in the degree of physical access that creates inequalities in schools (Valadez \& Durán, 2007). For example, Valadez and Durán (2007) found that teachers in well-resourced schools had access that is more physical and used ICT more frequently than those in poorly resourced schools. Materials and access to resources are directly influenced by income (Ghobadi, \& Ghobadi, 2013; Van Dijk, 2013). Research has also shown that teachers in well-resourced schools are more eager to use various ICTs in their teaching and motivate their students to communicate and engage in classroom activities. These findings also affect students in well-resourced schools, who are more likely to use ICT for experimental and creative purposes than students in poorly resourced schools (Valadez \& Durán, 2007).

Similarly, people with disabilities seem to have less ICT access and use, due to exclusion factors, such as economic and social attitudes (Chadwick et al., 2013). Device complexity also makes it difficult for some disabled students to use ICT use for some disability's students (Palmer, Wehmeyer, Davies, \& Stock, 2012). Different types of disability can influence an individual's degree of ICT access and use (Chadwick et al., 2013). Other challenges that can affect digital inclusion in the classroom include a lack of professional training for educators and a lack of funding and ICT-supportive resources (Ali et al., 2013; Al-Okaily, 2013; Chadwick et al., 2013). Flexible, open, and cost-effective technologies are needed to bridge the digital divide in inclusive classrooms (Kelley-Salinas, 2000). Schools need appropriate technical support, available at all times, to help teachers and students overcome various technical difficulties that make it difficult to access and use ICT (Al-Okaily, 2013).

\subsection{Digital Skills and Usage}

The motivation to use technology in the classroom is not enough; teachers must adopt new programs, explore web platforms, and subscribe to various applications to support their teaching. To actually use technology, people must know why, when, and how to use ICT; they must have competencies and frequent opportunities to use it in creative ways (Van Dijk, 2017). For this reason, teachers who use ICT more frequently can inspire students to develop technological access and skills. Teachers must however identify the specific types of technology that suit their own students in inclusive classrooms. For example, students with disabilities may require assistive technologies, such as hearing or vision aids, to participate actively in the classroom (Lyons \& Tredwell, 2015). To use these assistive technologies, teachers, students, and their parents will need training (Lyons \& Tredwell, 2015). In the modern digital era, parents play a significant role 
in mediating their disabled and non-disabled children's ICT use and developing their skills. The parents' own ability to use ICT influences their children's ICT use (Kelley-Salinas, 2000; Yuen et al., 2016).

When it comes to the issue of effective ICT implementation in inclusive education, researchers have questioned whether the digital divide is a significant issue for learners with disabilities (Wu et al., 2014). Wu et al. (2014) investigated whether there was a digital divide between non-disabled students and those with learning disabilities (LD) in Taiwan. The study employed a self-reported questionnaire that covered degrees of access to ICT, ICT competency, and digital participation rates among elementary-school students. The study recruited 117 learners with disabilities and a similar number of non-disabled students - a total research sample of 234 participants. Although the study found no difference between disabled and non-disabled learners' levels of access to computers or the Internet at home or in school, the authors did find that learners with disabilities had lower levels of ICT competency than their normal colleagues. The study identified a need for an ICT curricula specifically designed for students with disabilities.

According to Seale, Georgeson, Mamas, and Swain (2015), even when specialneeds students have equal access to ICT resources, the resources are not effective because the students need special assistive technologies. Disabled students face a digital divide in accessing and using suitable ICT resources to support their learning process. Lyons and Tredwell (2015) have proposed a five-step process for integrating technology into inclusive classrooms. The process starts by assessing the students' ICT background and skills, before involving students in developing rules for classroom ICT use. The third step uses ICT-program policies or the professional guidelines adopted by schools to mediate best practice and acquire suitable technology, based on the students' abilities and/or disabilities. The fourth step brings technology into the curriculum by selecting ICT resources that connect learning standards with instructional strategies, providing students with various equal-engagement classroom activities. The final step collects data through a formative assessment, monitoring the achievement of curricular objectives. By monitoring student progress, teachers are able to choose appropriate applications and tools to support learners with and without disabilities (Lyons \&Tredwell, 2015). The literature reveals that motivational, physical, and material access, digital skills, and usage constitute benefits of digital ICT; they also present challenges that can interfere with ICT use in inclusive classrooms. The literature suggests ways of narrowing narrow those gaps.

\section{Research Methodology}

This study has used a qualitative SWOT analysis, which was well suited to addressing the research questions. The underlying rationale behind this qualitative SWOT-analysis approach to research was to explore and assess the strength, weaknesses, opportunities, and threats of the digital divide in inclusive classrooms. The SWOT analysis explores and reflects on current situations and issues involving the digital divide in inclusive classrooms, demonstrating study validity (Phadermrod, Crowder, \& Wills, 2016). A SWOT analysis is considered a significant tool in situational analysis (Gürel, 2017). 


\subsection{Study Sample}

To explore the research question and achieve its purpose, the study engaged public school teachers and used purposive and snowball sampling as its qualitative sampling techniques. Purposive sampling is a type of non-probability sampling, in which the researcher draws a sample that reflects the type of participant of interest to the study. Snowball sampling was used to overcome the difficulties involved in accessing teachers (Cohen, Manion \& Morrison, 2011). The sample consisted of three women and three men $(n=6)$. All of the teachers worked in public schools, teaching different subjects to various grades in cycles two and three. The teachers had worked between three and twenty-seven years. Four held Master's degrees, while two held bachelor's degrees (see table 1).

Table 1: A table of participants

\begin{tabular}{|l|c|c|c|c|c|c|}
\hline \multicolumn{1}{|c|}{ Participant } & A & B & C & D & E & F \\
\hline Gender & Male & Male & Male & Female & Female & Female \\
\hline Grade & $5 \& 8$ & $10 \& 12$ & 12 & 9 & $9 \& 10$ & 9 \\
\hline School Type & Public & Public & Public & Public & Public & Public \\
\hline School Area & Al Ain & Al Ain & Al Ain & Al Ain & Al Ain & Al Ain \\
\hline $\begin{array}{l}\text { Years of } \\
\text { Experience }\end{array}$ & 15 & 27 & 19 & 13 & 3 & 11 \\
\hline Education & Master's & Master's & Master's & Bachelor's & Bachelor's & Master's \\
\hline Subject & English & English & Mathematics & English & Biology & English \\
\hline
\end{tabular}

\subsection{Data Collection}

An individual semi-structured interview, including both open- and close-ended questions, was used in this study. Open-ended questions are essential for promoting further exploratory research; close-ended questions help to identify demographic tendencies in the responses provided. The interviews covered background information, such as grades taught, overall experience, and the highest level of participant education. They also included questions about the SWOT analysis (Strength, Weakness, Opportunities, and Threat) (see Appendix A). Each interview took 20-30 minutes and was audiotaped. The interview questions were reviewed by a research expert to eliminate bias or ambiguity. To ensure the quality and internal validity of the interviews, each transcribed interview was reviewed and confirmed by the participants.

\subsection{Data Analysis}

The semi-structured interviews were analysed using a thematic analysis approach. We coded the data by identifying the main themes, coding them, and classifying the participants' responses under the main themes (Cohen et al., 2011). We then linked the themes to the research question and SWOT analysis methodology, grouping the themes into four categories (Strengths, Weaknesses, Opportunities, and Threats [see Appendix C]) and incorporating these into the four-quadrant SWOT matrix that represented our results (Gürel, 2017). For example, similar views expressed by teachers were grouped together under each category in the matrix. 


\section{Results}

The four SWOT-analysis groups were used as the main categories in our findings, followed by the emergent themes, to address the research question: What are primary-school teachers' views on the strengths, weaknesses, opportunities, and threats associated with equal ICT access and use in inclusive classrooms? Figure 2. Illustrates the strengths and other SWOT analysis findings.

\section{ICT Strengths in Inclusive Classrooms}

Three main themes emerged from the interview analysis, based on the strengths that teachers associated with accessing and using ICT in inclusive classrooms; these are discussed below.

Equal access. Most teachers (A, B, C, D, and E) said that there was no digital divide in their classrooms when it came to physical access to ICT, as all students had equal access to ICT resources. For example, Teacher A said, "All [specialneeds students] access it like other students [students without a disability]." Teachers B and C also indicated that they used ICT in their daily lessons; teacher B said that [he] "use[d] almost the same kind of technology with all the students." Similarly, teachers D and E commented, "all students have equal access to ICT."

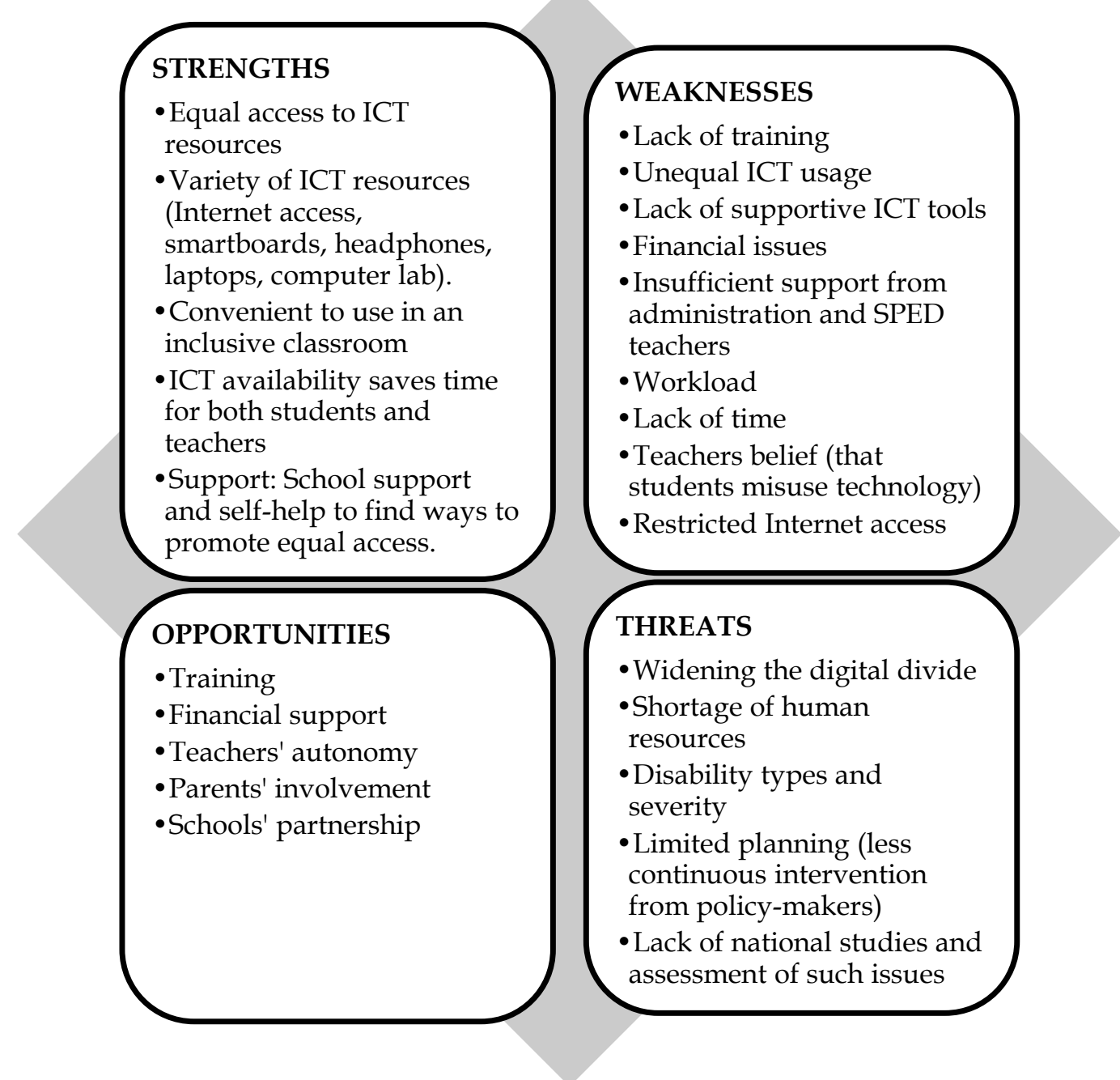

Figure 2. A SWOT Analysis of the Digital Divide in Inclusive Classrooms (Teachers' Views) 
The benefits of using ICT in inclusive classrooms. All of the teachers acknowledged that ICT offered some benefits in inclusive classrooms. The benefits included convenience of use, saving time, facilitating the teaching and learning process, and engaging and supporting special-needs students. According to teacher B:

"[ICT] makes the process of teaching easier for me when I use technology... [It challenges] the students to get ideas faster... I can use the Internet to download pictures, for example, which makes things easier and faster for me. So, this technology saves time for both the students and me."

Teacher D agreed that ICT "reduces time and effort." Teacher A reported, "[he] feels that the students are more engaged when [he] uses these ICT strategies and tools." Similarly, teacher F stated, "ICT or technology helps students to achieve more, especially those with special needs, particularly when it comes to hearing or vision aids or tools ....also, the interactive games attract them and help them learn better."

Other issues. Some teachers (B, C, and D) saw various ICT resources, such as Internet access, the computer laboratory, laptops, headphones, and smartboards, as a strength that supported equal access to technology for students with and without disabilities. As teacher, B said:

"We have access to the Internet...I always use YouTube videos to introduce some ideas for the students...we have smartboards and a resource center [that] can help students in their learning."

Teacher C stated that he used "some applications to jot down some [mathematical] functions...students have laptops in the classroom." Similarly, teacher D indicated that students had similar levels of access to various kind of ICT resources. However, teachers $B$ and $C$ mentioned that their school administration supported them in finding ways to promote equity in access, while teachers A and F depended on self-help, using differentiated instruction. As teacher A stated: "I depend on myself [to] support these students. Unfortunately, I cannot provide other resources for them." Likewise, teacher F said, "I always try to give everyone a fair chance and cater for different learning styles; I try to vary my technology [use] to address student needs."

\section{ICT Weaknesses in the Inclusive Classroom}

In relation to obstacles, the main theme that emerged involved problems with accessing and using ICT in inclusive classrooms. All of the teachers believed that a lack of training was the most significant impediment to equal ICT usage in their classrooms. For example, teacher F stressed that teachers "lack training in how to use ICT for special-needs students...MS certification does not give [us] a lot of training in this area [inclusive classrooms]." Three teachers (A, D, E, and D) pointed to inequities in ICT usage among students with and without disabilities. They emphasized that the special-needs students were not as engaged in ITC as their non-disabled classmates. The reason, according to teacher A, was "because they have different characteristics, they need special tools and equipment [to facilitate equal engagement]." 
Teacher F also highlighted the lack of ICT resources: "there are also schools who don't [have the tools], especially in remote areas." Financial issues were considered a factor that produced inequalities in ICT use in inclusive classrooms. Teacher E believed that such inequalities were due to the type and severity of the students' disabilities, while teacher $\mathrm{F}$ believed that teachers' unwillingness to teach was a factor that hindered the effective use of ICT. Other reported factors were the lack of time (D, E, and F) due to the "intensive curriculum," a lack of cooperation between general and special-needs teachers (A, C, and D), limited teacher autonomy (E and $F)$, misuse of technology (C and $F)$, large class size $(E)$, and restricted Internet access $(\mathrm{F})$.

\section{Opportunities}

All of the interviewed teachers made the same suggestion: to provide training programs to help teachers identify the best ICT resources and strategies for use in inclusive classrooms. According to teacher E:

"All teachers are focusing on their job, and they always want to be better and more helpful [to] their students, so if there is more professional training, everything will be [good]."

Teachers (A and F) suggested that school teams should allocate a reasonable budget for assistive technologies and tools to support students with disabilities. As teacher A said, "We should provide the resources and budget that are necessary to deal with them." Teacher F said more specifically, the "administration will use the funds to support special-needs students and buy equipment and teaching tools to help them."

Autonomy or professional independence was another idea proposed by teachers (E and F) to help teachers make decisions to support student learning. As teacher E said, "the support for teachers is to [let the teacher decide]." Similarly, teacher F said: "Unfortunately, teachers don't have the authority to download any application on school computers...we need support from the ADEC [Abu Dhabi Education Council] or Ministry of Education to let us have the authority to download applications or access websites that [are] useful for our students."

Teachers A and F identified a need for parental involvement to give students with disabilities access to ICT. However, teacher D pointed out the importance of establishing a school partnership to exchange information about and benefit from various experiences. Teacher A summarized the opportunities in one statement:

"If we want to really engage these students and help them, we should have enough staff, enough budget, enough resources, [and] enough training for teachers."

\section{Threats}

Three teachers (A, E, and F) felt that staff shortages were a threat that could exacerbate the digital divide in inclusive classrooms. Teacher A predicted that the gap would increase in future:

"Because [for] five years or more we still have the same problem, and nothing happened before they [policymakers] paid more attention to these 
students [special needs students], but now the attention has decreased, rather than increased."

Similarly, teachers D and F expressed concern about inadequate planning and interventions from policymakers on issues such as providing technical support, resources, and classroom assistants. Teachers A, D, and E were concerned about the different types of disability and the need to provide equal ICT access and usage. Teacher $\mathrm{F}$ addressed the lack of national studies and assessments of this issue.

\section{Discussion}

Like $\mathrm{Wu}$ et al. (2014) and Van Dijk (2017), the present study found that all students, with or without disabilities, had equal access to the ICT resources in their classrooms. Surprisingly, various factors expanded the digital divide for special-needs students in Abu Dhabi schools; these factors included the type of disability, a lack of training, resources, financial and technical support, a lack of time, the overall workload, restricted Internet access, and a shortage of human resources (Figure 2). Other researchers reported similar results in relation to students with and without disabilities (Ali et al., 2013; Al-Okaily, 2013; Basak \& Govender, 2015; Dobransky \& Hargittai, 2016; Lyons \& Tredwell, 2015; Martínez, 2011; Raman \& Yamat, 2014). In a study of types of disability, special-needs students were seen to be more disadvantaged in relation to effective ICT usage than students without disabilities (Chadwick et al., 2013; Dobransky \& Hargittai, 2016; Lidstrom and Hemmingsson). For this reason, the main finding was that special-needs students are thought to be less engaged in using ICT, even with equal access. Seale et al. (2015), who emphasized the need for assistive technology to promote equity in inclusive classrooms, have reported similar findings.

Few teachers mentioned the benefits of using ICT in inclusive classrooms; most benefits related directly to general classrooms. This finding shows that the teachers were largely unaware of the advantages of technology for special-needs' students; they were not necessarily motivated to explore them. For this reason, students with disabilities might not get the ICT support they needed. However, this can be explained by the teachers' lack of time and training and their extensive curricula and workloads; these factors can make teachers wish to integrate active ICT access and usage in their instruction (Ghobadi, \& Ghobadi, 2013; Raman \& Yamat, 2014). The teachers also said that adequate resources would motivate them to adopt appropriate ICT strategies (Valadez \& Durán, 2007) to promote equity in inclusive classrooms.

Importantly, the teachers were found to need training on how, when, and why to use ICT (Van Dijk, 2017). Training would not only provide teachers with the competencies needed to motivate them and their students to use ICT dynamically, but would also allow them to differentiate their technology use, based on student needs and disabilities. Professional training should be continuous, as the ICT field is constantly evolving. Lyons and Tredwell (2015) reflected on the training argument by highlighting the need to involve students and their parents in training, to promote favorable ICT integration. Such involvement could have a positive effect on special-needs students' ability to use technology creatively. A collaboration between various stakeholders, such as school administrators, 
teachers, special-needs educators, and parents can create an excellent foundation for supporting equal ICT access and use in inclusive classrooms.

\section{Limitations and Recommendations for Future Research}

Although this study has delivered significant insights on the topic of the digital divide in inclusive classrooms within the UAE educational context, it is nevertheless a preliminary investigation. The limitations of the study include the small sample size, drawn from one Emirate (Abu Dhabi); future studies should aim to give a satisfactory answer to the research question, while ensuring generalizability. Further studies with different methodologies, involving a larger group of participants that includes students, teachers, parents, and school administrators, could provide a fuller picture of the digital divide within a similar context. Furthermore, researchers should consider the ICT access and use of students with disabilities at home, as well as in school, to obtain a broader picture.

\section{Conclusions}

This study has explored teachers' views on the digital divide in inclusive classrooms. It has discussed the strengths, weaknesses, opportunities, and threats associated with equity in accessing and using ICT - for students with and without disabilities. The findings identified several weaknesses and threats, as well as various strengths and opportunities, exploring suggestions in the literature and discussing ways to overcome them. Overall, the results revealed that disabled students had equal access to available ICT resources in the classroom. However, special-needs students were seen as less engaged and more disadvantaged than their classmates were when it came to using ICT. Many factors were perceived to extend the digital divide; these included a lack of training, time, resources, funds, and types of disability. The teachers agreed that training was a necessary solution to reduce the effect of the digital divide in inclusive classrooms.

\section{Implications for Practice}

The study raises questions about equity in inclusive education. School administrators and teachers should examine their ICT practice and policies, not just to ensure equal access, but also to include digital competencies and effective and creative uses of ICT for students with and without disabilities. The study has exposed various factors that school administrators and teachers should consider; it has also suggested some solutions and ways to create a culture of equity by using technology to support disadvantaged students. The present study provides guidance on ways to formulate an appropriate digital-inclusion school policy for inclusive education. 


\section{References}

Ali, A. (2013). Etiquette, e-etiquette and cell phone use in the classrooms. Issues in Information Systems, 14(2), 452-462.

Al-Okaily, R. (2013). Mobile learning and BYOD: Implementation in an intensive English program. Learning and Teaching in Higher Education: Gulf Perspectives, 10(2), 1-17. doi:10.18538/lthe.v10.n2.141

Anati, N. M. (2012). Including Students with Disabilities in UAE Schools: A Descriptive Study. International Journal of Special Education, 27(2), 75-85.

Arias, M. (2019). Examining the digital disability divide in higher education. (Doctoral thesis, George MAson University). Retrieved from https:// search.proquest.com/docview/2316838714?pq-origsite=gscholar

Asiimwe, E. N., \& Khan, S. Z. (2013). Ubiquitous Computing in Education: A SWOT Analysis by Students and Teachers. QScience Proceedings, 18, 1-8. doi:10.5339/qproc.2013.mlearn.18

Basak, S. K., \& Govender, D. W. (2015). Development of A Conceptual Framework Regarding the Factors Inhibiting Teachers Successful Adoption and Implementation of ICT in Teaching and Learning. International Business $\mathcal{E}$ Economics Research Journal (IBER), 14(3), 431. doi:10.19030/iber.v14i3.9208

Batorowicz, B., Missiuna, C. A., \& Pollock, N. A. (2012). Technology Supporting Written Productivity in Children with Learning Disabilities: A Critical Review. Canadian Journal of Occupational Therapy, 79(4), 211-224. doi:10.2182/cjot.2012.79.4.3

Chadwick, D., Wesson, C., \& Fullwood, C. (2013). Internet Access by People with Intellectual Disabilities: Inequalities and Opportunities. Future Internet, 5(3), 376397. doi:10.3390/fi5030376

Clarida, B. H., Bobeva, M., Hutchings, M., \& Taylor, J. (2015). Strategies for Digital Inclusion: Towards a Pedagogy for Embracing and Sustaining Student Diversity and Engagement with Online Learning. IAFOR Journal of Education, 3, 86-106. doi:10.22492/ije.3.se.06

Cohen, L., Manion, L., \& Morrison, K. (2011). Research methods in education (7th ed.). London: Routledge.

Damodaran, L., \& Sandhu, J. (2016). The role of a social context for ICT learning and support in reducing digital inequalities for older ICT users. International Journal of Learning Technology, 11(2), 156. doi:10.1504/ijlt.2016.077520

Dobransky, K., \& Hargittai, E. (2016). Unrealized potential: Exploring the digital disability divide. Poetics, 58, 18-28. doi:10.1016/j.poetic.2016.08.003

Elen, J., Clarebout, G., Sarfo, F. K., Louw, L. P., Pöysä-Tarhonen, J., \& Stassens, N. (2010). "Computer" and "Information and Communication Technology:" Students' Culture-Specific Interpretations. Educational Technology \& Society, 13(4), 227-239.

Ghobadi, S., \& Ghobadi, Z. (2013). How Access Gaps Interact with Each other and Shape the Digital Divide: A Cognitive Investigation. Behaviour $\mathcal{E}$ Information Technology, 1-37. doi:10.1080/0144929x.2013.833292

Gürel, E. (2017). Swot Analysis: A Theoretical Review. Journal of International Social Research, 10(51), 994-1006. doi:10.17719/jisr.2017.1832

Kelley-Salinas, G. (2000). Different educational inequalities: ICT an option to close the gaps. In Learning to bridge the digital divide (pp. 21-36). Paris: Organisation for Economic Co-operation and Development.

Knott, C. L., Steube, G., \& Yang, H. (2013). Technology In The Classroom Versus Sustainability. Contemporary Issues in Education Research (CIER), 6(1), 9. doi:10.19030/cier.v6i1.7600 
Leatherman, J., \& Niemeyer, J. (2005). Teachers' Attitudes Toward Inclusion: Factors Influencing Classroom Practice. Journal of Early Childhood Teacher Education, 26(1), 23-36. doi:10.1080/10901020590918979

Lidström, H., \& Hemmingsson, H. (2014). Benefits of the use of ICT in school activities by students with motor, speech, visual, and hearing impairment: A literature review. Scandinavian Journal of Occupational Therapy, 21(4), 251-266. doi.org/10.3109/11038128.2014.880940

Lyons, C. D., \& Tredwell, C. T. (2015). Steps to Implementing Technology in Inclusive Early Childhood Programs. Computers in the Schools, 32(2), 152-166. doi:10.1080/07380569.2015.1038976

Jupin, J. (2019). A study of the implementation of digital textbooks in middle schools. (Doctoral thesis, Concordia University, Portland). Retrieved from https:/ / search.proquest.com/docview/2247183897?pq-origsite=gscholar

Martínez, R. S. (2011). Disability and the use of ICT in education: Do students with special needs recognise the support given by teachers when using technology. Problems of Education in the 21st Century, 35, 149-158.

Mølster, T. (2016). What About ICT for Students with Reading and Writing Difficulties? EDULEARN16 Proceedings. doi:10.21125/edulearn.2016.1370

Moriña, A. (2017). Inclusive education in higher education: Challenges and opportunities. European Journal of Special Needs Education, 32(1), 3-17. doi:10.1080/08856257.2016.1254964

Obradović, S., Bjekić, D., \& Zlatić, L. (2015). Creative Teaching with ICT Support for Students with Specific Learning Disabilities. Procedia - Social and Behavioral Sciences, 203, 291-296. doi:10.1016/j.sbspro.2015.08.297

OECD Secretariat. (2000). Emerging Trends and Issues: The Nature of the Digital Divide in Learning. In Schooling for Tomorrow: Learning to Bridge the Digital Divide (pp. 5162). Paris: OECD Publications Centre.

Palmer, S. B., Wehmeyer, M. L., Davies, D. K., \& Stock, S. E. (2011). Family members' reports of technology use by family members with intellectual and developmental disabilities. Journal of Intellectual Disability Research, 56(4), 402-414. doi:10.1111/j.1365-2788.2011.01489.x

Phadermrod, B., Crowder, R. M., \& Wills, G. B. (2016). Importance-Performance Analysisbased SWOT analysis. International Journal of Information Management, 44, 194-203. doi:10.1016/j.ijinfomgt.2016.03.009

Raman, K., \& Yamat, H. (2014). Barriers Teachers Face in Integrating ICT During English Lessons: A Case Study. The Malaysian Online Journal of Educational Technology, 2(3), 11-19.

Sahito, Z., \& Vaisanen, P. (2017). The Effect of ICT Skills on the Job Satisfaction of Teacher Educators: Evidence from the Universities of the Sindh Province of Pakistan. International Journal of Higher Education, 6(4), 122. doi:10.5430/ijhe.v6n4p122

Seale, J., Georgeson, J., Mamas, C., \& Swain, J. (2015). Not the right kind of "digital capital?" An examination of the complex relationship between disabled students, their technologies, and higher-education institutions. Computers $\mathcal{E}$ Education, 82, 118-128. https://doi.org/10.1016/j.compedu.2014.11.007

Sossa, S. F., Rivilla, A. M., \& González, M. L. (2015). Digital inclusion in education in Tarija, Plurinational State of Bolivia. CEPAL Review, 2015(115), 63-80. doi:10.18356/fa19c5da-en

Valadez, J. R., \& Durán, R. P. (2007). Redefining the Digital Divide: Beyond Access to Computers and the Internet. The High School Journal, 90(3), 31-44. doi:10.1353/hsj.2007.0013 
Van Dijk, J. (2012). The Evolution of the Digital Divide: The Digital Divide turns to Inequality of Skills and Usage. In Digital Enlightenment Yearbook 2012 (pp. 57-75). Amsterdam: IOS Press. doi:10.3233/978-1-61499-057-4-57

Van Dijk, J. (2017). Digital Divide: Impact of Access. In Rössler, P., Hoffner, C. A., \& Zoonen (Eds.), The International Encyclopedia of Media Effects (pp. 1-11). Chichester, West Sussex: John Wiley \& Sons. doi:10.1002/9781118783764.wbieme0043

Van Dijk, J. A. G. M. (2013). A theory of the digital divide. In M. Ragnedda, \& G. W. Muschert (Eds.), The digital divide: the Internet and social inequality in international perspective (pp. 29-51). Milton Park, Abingdon, Oxon: Routledge.

Warf, B. (2018). Teaching Digital Divides. Journal of Geography, 1-11. doi:10.1080/00221341.2018.1518990

Wu, T., Chen, M., Yeh, Y., Wang, H., \& Chang, S. C. (2014). Is the digital divide an issue for students with learning disabilities? Computers in Human Behavior, 39, 112-117. doi:10.1016/j.chb.2014.06.024

Yuen, A. H., Park, J., Chen, L., \& Cheng, M. (2016). The significance of cultural capital and parental mediation for digital inequity. New Media \& Society, 20(2), 599-617. doi:10.1177/1461444816667084 


\section{Appendices}

\section{Appendix A}

\section{Semi-Structured Interview Questions}

1. Background Information:
A. What grade do you teach?
B. What subject you teach?
C. How long have you been teaching? (experiences)
D. What is your highest level of education?
E. School type
F. Area

2. Questions that investigate teachers' views of the advantages of using ICT in an inclusive classroom:
A. What are the advantages of using ICT in inclusive classroom?
B. What actions do you usually take to achieve equity when using ICT in an inclusive classroom?
C. What support do you get from school administrators to ensure equal access to ICT in inclusive classrooms?
D. What kind of ICT resources do you use to support equal access to ICT in your school?

3. Questions about the way in which teachers maintain weaknesses or are challenged for accessing and using ICT in inclusive classrooms:

A. Do all students (with and without disabilities) have equal access to ICT? How? (give examples).

B. What factors make it difficult for special-needs students to become equally involved in inclusive classrooms?

C. How do you maintain weaknesses; are you challenged for accessing and using ICT in an inclusive classroom? Explain.

4. Questions that deal with opportunities to use ICT effectively in inclusive classrooms:
A. How do other schools deal with similar issues?
B. What are some alternative solutions to the need to provide equal ICT access for students with and without disabilities?
C. What can support you in promoting equal access to ICT in inclusive classrooms? Explain.

5. Questions about the teachers' views of threats associated with ICT usage in inclusive classrooms:

A. What obstacles do you currently face in integrating ICT teaching in inclusive classrooms?

B. From your point of view, what obstacles are likely to make it difficult for teachers to maintain equal ICT access in inclusive classrooms?

C. What potential opportunities exist to increase the digital divide in inclusive classrooms? 


\section{Appendix B}

\section{Final list of codes:}

\begin{tabular}{|c|c|}
\hline Strengths & $\begin{array}{ll}- & \text { Equal access } \\
\text { - } & \text { Benefits of ICT } \\
\text { - } & \text { Other issues } \\
\text { - } & \text { ICT resources } \\
\text { - } & \text { Support teaching \& learning } \\
\end{array}$ \\
\hline Weakness & $\begin{array}{ll}\text { Obstacles } \\
\text { - } & \text { Training } \\
- & \text { Supportive resources } \\
- & \text { Time } \\
- & \text { Workload } \\
- & \text { Budget } \\
- & \text { Collaboration } \\
- & \text { Restriction on Internet use }\end{array}$ \\
\hline Opportunities & $\begin{array}{ll}\text { - } & \text { Training } \\
\text { - } & \text { Budget } \\
\text { - } & \text { Autonomy } \\
\text { - } & \text { Parental involvement } \\
\text { - } & \text { School partnership } \\
\end{array}$ \\
\hline Threats & $\begin{array}{ll}\text { - } & \text { Staff shortages } \\
\text { - } & \text { Digital divide } \\
\text { - } & \text { Type of disabilities } \\
\text { - } & \text { Planning } \\
\text { - } & \text { National research } \\
\end{array}$ \\
\hline
\end{tabular}

